\title{
NOTES ON AN OCCASIONALLY NETTLESOME SHORT STORY OF MIGUÉIS ${ }^{1}$
}

\author{
John Austin Kerr, Jr.
}

At first glance, "Dezasseis Horas em Missão Secreta" would not appear to be the sort of work which embroils one in literary problems. It flows smoothly, as is the usual case with the works of its author, José Rodrigues Miguéis. It is a gripping mystery tale, yet a linghthearted one. It is intriguingly cosmopolitan, in that there are reflections of Central American revolutionary struggles cast against a European background in a tale told in Portuguese by a Portuguese writer.

However, there are indeed some nettlesome questions which arise from a closer reading of this short work and certain of the criticism which exists on it. How, for example, is a critic to judge an entertaining piece of fiction? Where is it set in terms of historical time? Is it one of Miguéis' "German" stories, in terms of its setting, at least? What are some of the serious elements, if any, of its social thematic content? What is the role of its psychological thematic content, if any? Are there links between this somewhat atypical short story (in the sense that Miguéis is not primarily a mystery writer) and other works of the author's?

In view of the foregoing, therefore, and with a view to answering some of these questions at least partially, I propose a brief examination of the following aspects of "Dezasseis Horas em Missão Secreta:" its critical situation; its setting in terms of time and place; its social and psychological thematic content; and, finally, a few links that exist between it and other works of Miguéis' corpus. First, though, I take the liberty of including a synopsis of the story, as it has been nearly a decade since the last time it was republished as a part of Léah e Outras Histórias, and because I hope to point up a measure of its jocular tone in this manner.

When we first immerse ourselves in this short story, we meet a dedicated Central American counter-revolutionary as he arrives at a destination somewhere in Northern Europe. A cultured man, he is thrilled by his first visit to that continent. However, a stern duty weighs heavily upon him, for he is nothing less than a political assassin, a volunteer from the ranks of the liberal underground opposition to an oppressive military government which has taken over his country by means of a short but bloody revolution. His mission: to murder on the following day one of the most hated men of the military regime, His Excellency the Ambassador of the "Centralian Federal Republic." 
In the meantime, however, he must find food and shelter. Unfortunately, he is a bit disoriented in the huge industrial city, and once or twice he is tempted to discard his pistol and forget the whole matter. His keen sense of duty will not allow this, however, and he eventually encounters a friendly plumber who tells him where the nearest lodgings are to be found and who even puts him onto the proper bus. The bus driver, in turn, very kindly detours from his normal route in order to help the stranger arrive at his destination, which turns out to be a Baptist hostel.

He finds it clean, modern and inexpensive, but the young American pastor from the Middle West is most condescending and the other boarders seem to be interested mainly in the cheap room and board, so the nameless protagonist feels compelled to escape the peculiar atmosphere of the place by going out to a movie after dinner. This he does, even though he must first obtain a key to the front door and special permission from the pastor to stay out until midnight. He is warned, moreover, that this is a special favor conceded him only because he is a foreigner and an educated man, and that he must return by twelve o'clock on the dot, or else.

Nevertheless, the narrator-protagonist is a little late in getting back. He discovers that the front door has been locked and bolted from the inside, rendering his key useless. Neither, he finds, can he rouse anyone inside the hostel, even though he can see from a shadow cast on a lighted window that the pastor is still awake. Furiously, he stamps off into the night, all thoughts of his deadly mission forgotten.

The prospective political assassin then takes to wandering aimlessly about the great European capital, entranced by his new surroundings. He is lonely, but with a sense of conscious virtue he rebuffs the advances of the prostitutes he encounters. Eventually, when it is well past one o'clock in the morning, he enters a dingy café-hotel in order to get a drink and inquire about a room for the night. As he opens the door; an alarm-bell rings and the three people inside look at him in consternation: the bartender, his wife, and a barmaid. Realizing that he is the only customer, he invites the others to drink with him and one thing leads to another. Soon the pretty, well-proportioned barmaid, Grete, is sitting invitingly close. Encouraged by this and reminding himself that it may be his last night ever, he asks about a room. Seductively, Grete shows him to a shabby cubicle upstairs, kisses him ardently and leaves with a promise to return after her employers have gone to bed.

She does return a few minutes later, but in a state of alarm. Another guest has had a seizure of some sort and must be gotten to his suburban home in secret, for he has been using the place as a convenient spot at which to meet his paramour. Would the protagonist help? Lured by Grete's comely figure and sensual promise, he assents.

The sick man, swathed from head to toe in a sheet, seems suspiciously inert and heavy to the Central American but he, Grete and the bartender's wife manage to get him bundled into a taxi. They set off for the suburbs with a well-muffled man doing the driving. Grete asks that the windows be closed and curls up against the prospective assassin. The route is long and tortuous, and the protagonist estimates that they must be very far from the center of the city before they stop. Curiously, they are not in a residential suburb but next to an enormous railway yard. The driver of the car explains, 
however: the best way to arrive at the bon-vivant's house is to cut across the rail yard. There is nothing for it but to carry the man across the tracks.

When they get about half-way across, however, the driver suddenly stops and curses. He has forgotten the house keys they had found in the man's pocket back in the glove compartment of the car. Grete is sent to retrieve them. The two men rest after having first deposited their cargo carefully on the gravel of the roadbed.

A minute or two later, the Centralian hears the unmistakable click of a knife being snapped open. He whirls, gun in hand, just in time to save his life: an instant's hesitation and the driver would have stabbed him in the back. Clearly, however, the latter was unprepared for the Centralian's lightning reaction and superior weapon. The knife clatters to the gravel of the roadbed.

With this, the protagonist's latent suspicions about the nature of their burden are quickly confirmed by the driver, who turns out to be the bartender in disguise. They have been attempting to dispose of the body of a dead man. Not only that, but the bartender and his wife have planned to fix the blame on the Central American, whom they have suspected of being a secret agent. Laughing inwardly at this and thanking his lucky stars for the month of pistol practice that he had undergone in his homeland, the protagonist retreats to a safe distance and then flees, racing across the tracks to safety.

The next morning, after having slept for a few hours in a cheap hotel of the sort that asks no questions and requires no documents, the counter-revolutionary buys a paper and glances idly through it as he munches on his breakfast of black bread and scalding synthetic coffee. A late bulletin happens to catch his eye. Scarcely believing what he is reading, he learns that the Ambassador of the Centralian Federal Republic has been found strangled in a rail yard. The Centralian Embassy has already charged that the murder was the work of Centralian terrorists, but the local police and secret service feel that the Ambassador, well-known for his wining, wenching and gambling, was simply ambushed and murdered for his money.

His pulse pounding, the frustrated assassin races back to the Baptist hostel to retrieve his documents, which he had had to leave with the pastor the night before. He is received with glacial disapproval, pays his bill and departs, but not before cheerfully telling the minister that he has had an admirably productive evening of it. Only after he is safely in the air aboard an international flight does he recover enough composure to re-read the article and congratulate himself for having set a record, for " . . . sem manchar as mãos de sangue... eu conseguira desempenhar em dezasseis horas apenas a minha difícil missão secreta." ${ }^{2}$ But, he wonders, could Grete's kisses possibly have been sincere?

Perhaps only when we examine the reviews and criticism on Miguéis' Páscoa Feliz do we encounter the variety of opinion that exists on this short story. Armando Ferreira, " dentro de pormenores preciosos de vida vivida nos fundos misteriosos de uma 
cidade estrangeira." ${ }^{\prime 3}$ Another reviewer liked the richness of local color and compared it to the way Miguéis had captured elsewhere the atmosphere of New York and Lisbon. ${ }^{4}$ João Pedro de Andrade agreed with Armando Ferreira in that he considered it to be a good suspense story, but flawed by its "... desenlace folhetinesco." 5 This view, however, tended to ignore the complex novelty of an idealistic prospective political assassin who in the end does not have to commit murder because he himself is nearly killed in an attempt by others to make it appear that he is responsible for the murder of his own intended victim.

The other side of the coin, however, is totally different. An anonymous reviewer for the Diário de Noticias called this story a work “... de segunda escolha, onde o acaso ou um sentimentalismo destoante da sua ironia jovem e irreverente assume papel de excessiva importância." $\mathrm{He}$ went on to say that he considered it and "Uma Carreira Cortada" to be mere "... contos de magazine ..." leaving unclear whether he meant literary magazines or popular ones. Far more acerbic, however, were the comments of the well-known Lisbonese novelist, critic and reviewer, João Gaspar Simões. He stated that he thought that "Dezasseis Horas em Missão Secreta" was a story "... que podia ter sido louvado pelo público do Reader's Digest, mas que literàriamente é o tipo de novela que um escritor de raça não escreve ..." "8 After noting that elsewhere the author " ... é irresistivelmente levado a lidar com um ambiente social e um material humano que por serem no fim de contas os mesmos que o autor de Os Maias viu com os seus olhos de civilizado ...," "9 Gaspar Simões returned to his attack on "Dezasseis Horas em Missão Secreta" and repeated his conviction that the story was "... bem pouco digna de um verdadeiro escritor ..." ${ }^{10}$ Finally, after making a few positive remarks about "Pouca Sorte com Barbeiros" and "O Morgado de Pedra-Má,"11 this critic came to his general, and exceedingly deprecatory, conclusion that Miguéis was “... um prosador que ainda não teve tempo de se chegar a conhecer completamente." ${ }^{12}$ In view of these remarks, it is ironic that at the time, João Gaspar Simões was a member of the five-man panel which would award to José Rodrigues Miguéis the highest Portuguese literary prize for prose fiction less than three weeks after these words were published, and for the collection which contained "Dezasseis Horas em Missão Secreta."1 3

Be that as it may, even if one leaves aside Gaspar Simões' remarks about the Reader's Digest, which rather obviously refer to Miguéis' position as associate editor of that extremely well-known but popular American magazine, his cuttingly personal conclusion and his invidious comparison of Miguéis with Eça de Queiroz, which rather oddly implies that social conditions have remained static for the last hundred years, one is compelled to refute Gaspar Simões' contention that a good writer does not write mystery or suspense stories. If a good writer, even a great writer, is moved to write and publish fiction of this type, who can fairly say that he must not do so, in order to preserve the supposed sanctity of literature which is "good" because it is "serious?" Surely not a person who writes in the guise of a critic, even if he has himself produced original works. Last, this splenetic reviewer's comments obscure the important fact that "Dezasseis Horas em Missão Secreta" represents an example of Miguéis' extreme versatility in the treatment of his subject material in the general medium of prose fiction. 
- However, when all is said and done, these nettles in the critical picture on the work at hand must simply be taken firmly in hand and uprooted, no matter how great the discomfort. Or so it would seem to this student of Miguéis' works.

Passing on to the matter of the temporal and locational referents of this story, we find that, except for the information that everything takes place in sixteen hours one night and early morning during the month of October, ${ }^{14}$ the setting of this work in terms of time is quite imprecise. Because of the fact that it was first published separately (and under a pseudonym), in $1948,{ }^{15}$ the terminal date for this temporal aspect is apparently established. However, since it seems most probable that the country in which these events take place is Germany (as we shall see immediately below), this concrete date does not in fact help us, for there is absolutely no mention of damage resulting from World War II. The rail yards are described as being full of endless lines of cars and everything appears to be in perfect working order. ${ }^{16}$ Therefore, since it is highly unlikely that such could have been the case in 1948, it seems most probable that the period with which the author is dealing antedates World War II.

Similarly, the most that one can deduce as to the earliest temporal limit is that it falls after World War I because of the mention of regular airline service (pp.39-157). Furthermore, none of the effects or aftereffects of the Great War appear, which would tend to place the dating of the action closer to the decade of the 1930's, after Germany's industrial recovery was in full swing. In addition to this, there is the fact that the author visited Germany during the period in which he was pursuing advanced studies at the University of Brussels between 1929 and 1932. Therefore, all things considered, it seems best to conclude that the action of this story takes place over the short space of sixteen hours one October day during the early 1930's, although the matter does indeed remain problematical.

The locational aspect of the setting of "Dezasseis Horas em Missão Secreta" is also indicated by a handful of hints scattered throughout the story. They could apply to many a large industrial city, but there are signs that it is located in Germany. First of all, we are told that it is in Europe (p.137 and p.145) and that it lies at a high latitude (p.137). Then, there is the matter of the barmaid's German name, Grete (p.148 ff.). Later, towards the end of the story, there is a description of the Centralian's breakfasting on black bread and “ ... café sintético ..." (p.157), i.e., ersatz coffee. Last, the rail yard is located in "X-haven" (p.157 and 159), which could represent many a German toponym. Thus, while no single indication of the action's geographical location is at all conclusive, the weight of the slim evidence that does exist leads one to entertain the strong suspicion that this story is set in Germany, a country which lies within the area of the author's personal acquaintance. Note, however, that such a resolution of the matter is far from being a certain one, and that here again one is faced with another nettlesome question. Not so on the matter of its thematic content, however, for even though this story is a humorously exciting one, "Dezasseis Horas em Missão Secreta" does contain a backdrop of serious social problems. First of all, there are the root causes of the protagonist's being sent to Europe on a mission of assassination: a military revolution in the "Centralian Federal Republic" (pp.137-138) and the oppressive measures taken by the new government (p.138). While the name of the country is fictitious, these social phenomena have been all too frequent in real life since the beginning of the nineteenth 
century and before. They often unleash a reaction by more liberal elements, such as the ones alluded to here, often with the result that there is created an atmosphere of intrigue and violence. And this, of course, hardly tends to promote orderly social progress.

It is interesting to note, however, that even to the Ambassador's opprobrious goals in life, the problem of the revolution is treated on a personal level for the most part. The Ambassador himself loses his life because of his hedonistic inclinations, and the protagonist's life is changed as well. One gathers that he is not a killer in the ordinary sense, but that he has prepared himself to become one for ideological reasons. He is alone in a foreign land (p.139, p.141 and pp.147-148), although in contrast to the principal characters in other works of the author's, he naturally wishes to remain alone and incognito, for the most part. He is soon involved with the demimonde and its prostitutes (p.146), cheap hotels and venal characters such as the bartender, his wife and Grete (pp.149 ff.). These contacts also involve him in the complications of an illicit affair (pp. 150-159). He nearly loses his life (p.154) in an attempt by others to make it appear that he was responsible for a murder that had already been committed (p.155). Last of all, of course, he is faced with the prospect of leading the life of an exile, at least temporarily (p.157).

These are the main lines of the author's social criticism in this short story, but we do find another target for his sharp pen in the person of the uncharitable Baptist minister, who will not let the protagonist into the hostel after the curfew hour imposed upon him (pp.145-146), and who apparently seeks to trade inexpensive room and board for souls: in the author's telling phrase, he is a "... moço pastor de estômagos." (p.143). He is also pompous (pp.143-144) and overly strict (p.143). And all of this has the inevitable result that the other residents of the hotel give the impression of false piety. Here again, then, we have an example of the author's criticism of certain aberrations in organized religion. Here, however, the humorous nature of the medium allows Miguéis to criticise these faults more heavily: a fact that João Gaspar Simões and others have evidently failed to note.

Perhaps because of the story's tone, few problems of a psychological nature are evident in it. Basically, these consist of the protagonist's strong doubts as to his ability to carry out his mission (p.139), his fear of losing his self-control (p.139) and his initial fear of being alone (p.140) as he faces the unforeseeable events the immediate future will bring (p.140). However, they are not treated from the point of view of a person who is mentally ill, as was the case in Páscoa Feliz or "A Mancha não se Apaga," 7 but rather from that of one who is quite sane. Here they merely add elements of desirable tension to the action and help to characterize the protagonist. They are interesting subsidiary features of the story, therefore, but are not of central importance to it.

Regarding the correlations between this work and others of the author's, these are relatively few. However, two of them have been given an interesting twist. First, though, attention should be called to the figures of the friendly plumber and bus driver, who appear but fleetingly. ${ }^{18}$ Both of them would seem to belong to the lower class, and as elsewhere in Miguéis' corpus, we have a sympathetic view of it. In addition, there is another example of the role that premonition plays in Miguéis' prose fiction, in that the protagonist has a sudden feeling that the sick man might really be a corpse, as he is indeed (p.152). 
An interesting thing happens when we note the familiar symbol of the bloody hands (p.159) and the theme of seduction and abandonment (pp.148-154): both are treated in a manner different from that which is observable in other works. Thus, whereas in "Morte de Homem" the bloody hands were real and were imaginary in "A Mancha não se Apaga," 19 in this story they turn out not to exist at all, for in the end the progatonist has not had to assassinate the Ambassador. Similarly, the sensually-promising episode with Grete leads to no great success on the part of the protagonist: something quite different from the situation that obtains in "Léah," for example. Furthermore, the roles are the reverse of what one observes in the latter work: it is Grete who takes the lead, first in the seduction and then in the abandonment phases. One is enjoying, in sum, an interesting variety in the author's treatment of similar aspects of dissimilar works.

In general, therefore, it would appear from the foregoing that: critcs must be even-handed and intellectually resilient if they are to avoid clichés and serve their public - which pays for their services, after all; Miguéis has merely hinted - strongly - that the setting of this work is the pre-World-War II Germany that he himself visited, ${ }^{21}$ and is therefore one of his "German" stories; the social thematic content of the short story is both serious and centered on the main lines of Miguéis social criticism in other works of his; its psychological thematic content, on the other hand, is not of central importance to "Dezasseis Horas em Missão Secreta," although it does add to other aspects of the work; and finally, the links between this story and others that have come from Miguéis pen are few but interesting, in that they, too, tend to reflect Miguéis' artistic and social concerns, as exemplified elsewhere in his works. If one but keeps these things in mind, I submit, the reading of this delightful work should occasion very few nettlesome afterthoughts.

\section{Department of Foreign Languages and Literatures Northern Illinois University \\ DeKalb, Illinois - USA}




\section{NOTES}

${ }^{1}$ This paper was adapted from portions of my Ph.D. dissertation, Aspects of Time, Place and Thematic Content in the Prose Fiction of José Rodrigues Miguéis as Indications of the Artist's Weltansicht, The University of Wisconsin, Madison, U.S.A., 1970. It was written under the direction of Professor Jorge de Sena, to whom I am greatly indebted for his kind advice and stimulation over a number of years. Any faults, of course, are my own.

2 José Rodrigues Miguéis, Léah e Outras Histórias, 4th ed. (Lisbon: Estúdios Cor, 1968), p.159. This is the edition to which reference is made in this paper.

${ }^{3}$ Armando Ferreira, "Léah por Juś Rodrigues Miguéis," Jornal do Comércio (Lisbon), April 5/6, 1958, p.10.

4 "Léah e Outras Histórias, por José Rodrigues Miguéis," (anon.), O Primeiro de Janeiro, Das Artes e das Letras (Oporto), April 30, 1958, p.3. [This article, though unsigned, is generally considered to be by Jaime Brasil.]

5 João Pedro de Andrade, "Crítica: Léah e Outras Histórias - por José Rodrigues Miguéis," Diário Popular, Quinta-Feira à Tarde (literary supplement) (Lisbon), June 26, 1958, página central.

6 “'Léah e Outras Histórias' por José Rodrigues Miguéis,” (anon.), Diário de Notícias (Lisbon), July 6,1958 , p.5.

${ }^{7}$ Ibid.

${ }^{8}$ João Gaspar Simões, "Léah e Outras Histórias, por José Rodrigues Miguéis," Diário de Noticias (Lisbon), May 8, 1958, p.15.

9 J. G. Simões, “Léah por J. R. Miguéis," Diário de Notícias (Lisbon), May 8, 1958, p15. See also Eça de Queiroz, Os Maias, 2 vols. (Oporto: Lello \& Irmãos, n.d.). Originally published in 1888.

10 João Gaspar Simões, "Léah e Outras Histórias por José Rodrigues Miguéis," Diário de Noticias (Lisbon), May 8, 1858, p.15.

11 José Rodrigues Miguéis, "Pouca Sorte com Barbeiros" and "O Morgado de Pedra-Má," both in Léah e Outras Histórias, 4th ed. (Lisbon: Estúdios Cor, 1968), pp.91-114 and 229-267 respectively.

12 Gaspar Simões, p.15. It might be germane to recall at this point that Gaspar Simões was a well-known presencista, just as Miguéis was a well-known seareiro - both in the early days of Presença and Seara Nova. Furthermore, Simões' comments are strongly reminiscent of an equally unwarranted attack on Miguéis' writing ability by Albano Nogueira some twenty-six years earlier: " ... o autor de Páscoa Feliz, por uma lamentável precipitação, não quis concluir o trabalho necessário de completa autodescoberta." (Albano Nogueira, "Páscoa Feliz, Novela de José Rodrigues Miguéis," Presença, II, No. 36 [November 1932], 10-11). Nogueira and Simões were, of course, well known to each other-and to Miguéis.

13 "O Prémio Camilo Foi Concedido ao Escritor Rodrigues Miguéis," (anon.), Jornal de Notícias (Oporto), May 26, 1959, p.6.

14 José Rodrigues Miguéis, Léah e Outras Histórias, 4th ed. (Lisbon: Estúdios Cor, 1968), pp. 37-159.

15 José Rodrigues Miguéis, "16 Horas em Missão Secreta," Ver e Crer, No. 40, August 1948, pp.103-116. [Signed Phil McEvoy.] 
16 José Rodrigues Miguéis, Léah e Outras Histórias, 4th ed. (Lisbon: Estúdios Cor, 1968), pp.153-154. Inasmuch as the following references will be to this edition of this work, the page numbers will be given in the text between parentheses.

17 José Rodrigues Miguéis, Páscoa Feliz, 3rd ed. (Lisbon: Estúdios Cor, 1965) and "A Mancha não sc Apaga," in Onde a Noite se Acaba, 3rd ed. (Lisbon: Estúdios Cor, 1960), pp.69-99.

18 José Rodrigues Miguéis, Léah e Outras Histórias, 4th ed. (Lisbon: Estúdios Cor, 1968), pp.141-142. Inasmuch as the following references will all be to this edition of the work, page numbers will be given in the text between parentheses.

19 José Rodrigues Miguéis, "Morte de Homem," in Onde a Noite se Acaba, 3rd ed. (Lisbon: Estúdios Cor, 1960), pp.35-67 and "A Mancha não se Apaga," also in Onde a Noite se Acaba, pp.69-99.

20 José Rodrigues Miguéis, Léah e Outras Histórias, 4th ed. (Lisbon: Estúdios Cor, 1968), pp.7-36.

${ }^{21}$ For a brief bibliographical résumé, see my paper, "A Thumbnail Sketch of the Life and Works of José Rodrigues Miguéis," Proceedings of the Pacific Nortwest Council on Foreigh Languages, XXV (1) Literature and Linguistc 1974, pp.35-39, which is to be re-published in Littera (Rio de Janeiro). For a longer, if still necessarily partial, treatment of the author's life and works, see my book-length bio-bibliography, Miguéis - To the Seventh Decade, which is to be No. 29 of the series in Romance Monographs. 